\title{
A SUSTAINABILITY FRAMEWORK FOR ENGINEERING CARBON CAPTURE SOIL IN TRANSPORT INFRASTRUCTURE
}

\author{
B.W. KOLOSZ1 ${ }^{1}$ M.A. GODDARD ${ }^{1}$, M.E. JORAT ${ }^{1}$, J. AUMONIER ${ }^{1}$, S.P. SOHI ${ }^{2}$ \& D.A.C. MANNING \\ ${ }^{1}$ School of Civil Engineering and Geosciences, Newcastle University, UK. \\ ${ }^{2}$ School of Geosciences, Edinburgh University, UK.
}

\begin{abstract}
Recent research has demonstrated considerable potential for artificial soils to be designed for carbon capture. The incorporation of quarry fines enables the accumulation of atmospheric $\mathrm{CO}_{2}$ in newly formed carbonate minerals. However, the rate and trajectory of carbon accumulation has been little studied. The relative contribution of biotic (e.g. vegetation, micro-organisms) and abiotic (water, light, temperature) factors to the carbonation process is also unknown. This article presents a sustainability framework which aims to determine the multi-functionality of soils to which fines have been added not only in their role as carbon sinks but also in their role of providing additional opportunities for improvement to ecosystem services. Such frameworks are required specifically where land designed for $\mathrm{CO}_{2}$ capture must also provide other ecosystem services, such as flood mitigation and biodiversity conservation. Land within linear transport infrastructure provides a case study, focusing on 238,000 ha of vegetated land associated with roadside verges in the UK. Hypothetically this area could remove $2.5 \mathrm{t} \mathrm{CO}_{2}$ per year from the atmosphere, equivalent to $1 \% 2011$ total UK emissions or $2 \%$ of current transport emissions and saving an equivalent of $£ 1.1$ billion in non-traded mitigation values. Roadside verges should be designed to minimize flooding onto the highway and perform other important functions such as removal of dust and suspended solids from surface waters. Vegetation on 30,000 ha of railway land also provides opportunities for carbon sequestration, but management of this vegetation is subject to similar constraints to protect the rail tracks from debris extending from autumn leaves to fallen trees.

Keywords: carbon capture and storage, mineral carbonation, soil science, sustainability, urban transport.
\end{abstract}

\section{INTRODUCTION}

Carbon sequestration in soils is an important tool for meeting key sustainability targets and assisting in the mitigation of global climate change [1,2]. Although carbon capture and storage appears to be firmly associated with absorbing $\mathrm{CO}_{2}$ emissions from power stations (active capture), recent evidence indicates that passive carbon capture in urban soils may be feasible due to rapid reactivity of atmospheric $\mathrm{CO}_{2}$ with demolition-derived materials in soil [3]. Building carbon capture into urban green space and road-related infrastructure requires meeting specific criteria such as flood mitigation and managed plant growth.

Recent work at Newcastle Science Central (the former site of Newcastle Brewery, currently being developed for the planned 24 acres of mixed-use prime city-centre development land) in Newcastle-Upon-Tyne, UK, has revealed that urban soils can sequester up to $85 \mathrm{t} \mathrm{CO}_{2}$ /ha annually [3] through rapid precipitation in a soil of calcium carbonate (calcite, $\mathrm{CaCO}_{3}$ ). Based on this result, appropriate management of fewer than 12,000 ha of urban land

This paper is part of the proceedings of the 22nd International Conference on Urban Transport and the Environment (Urban Transport 2016)

www.witconferences.com 
has the potential to annually remove $1 \mathrm{t} \mathrm{CO}_{2}$ from the atmosphere by calcite precipitation, or 'carbonation'. Close examination of soil indicates a rapid carbon sequestration function, removing $\mathrm{CO}_{2}$ from the atmosphere and storing it as inorganic (pedogenic) carbon. During silicate weathering, calcium $(\mathrm{Ca})$ and magnesium $(\mathrm{Mg})$ silicate minerals naturally react with dissolved $\mathrm{CO}_{2}$ to form carbonates [4], effectively capturing and fixing atmospheric C. This formation of pedogenic carbonates contributes to the stabilization of atmospheric $\mathrm{CO}_{2}$ concentrations over various geological timescales $[4,5]$. The process is important in natural soils [6] but its extent in artificial soils has only been recently appreciated [7]. A simplified version of the carbonation reaction for artificial calcium silicates is given in Reaction 1 .

$$
\mathrm{CaSiO}_{3}+\mathrm{CO}_{2}+2 \mathrm{H}_{2} \mathrm{O} \rightarrow \mathrm{CaCO}_{3}+\mathrm{H}_{4} \mathrm{SiO}_{4}
$$

Materials such as dolerite (diabase) and basalt are anticipated to be highly effective in carbon absorption due to not only relatively high concentrations of calcium silicates but also the low embedded $\mathrm{CO}_{2}$ associated with their production, as there is no calcining involved (in contrast to cement/concrete). Carbonation of a single application of finely crushed dolerite in soil has been demonstrated to remove the equivalent of $18 \mathrm{t} \mathrm{CO}_{2}$ /ha annually over a 7-year period [8]. Current research, entitled 'Sustainable Urban Carbon Capture: Engineering Soils for Climate Change' (SUCCESS), at Newcastle University, UK, is exploring the potential for appropriate design of urban land to deliver carbon capture through carbonation and to also provide other ecosystem services [9]. Large-scale $\left(3 \times 4 \mathrm{~m}^{3}\right)$ trial plots were established in 2015 at Newcastle University's Cockle Park Farm (Fig. 1) using fines from a range of demolition and quarrying activities. The Cockle Park plots will provide a crucial insight into how to engineer artificial soil to sequester carbon whilst minimizing embedded life cycle emissions. Parallel

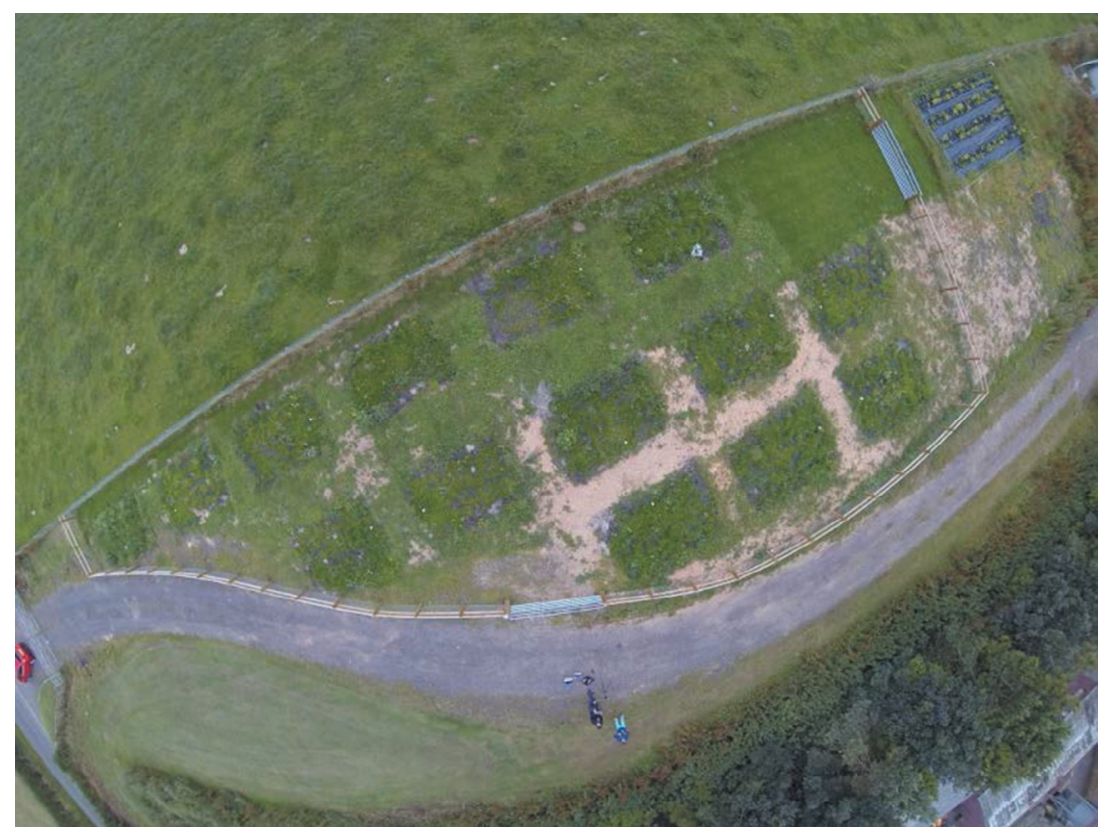

Figure 1: SUCCESS's Cockle Park experimental trial plots. 
plant growth trials are examining which plant species and functional types grow best on such artificial soils and the role of plants in facilitating carbon capture. Over 200 pots have been planted with 25 different plant species from a range of plant functional groups, such as grasses, trees and herbaceous plants, as well as some species that are grown as energy crops. The plant growth experiment makes use of two main substrates - crushed concrete and dolerite quarry fines - which are known to have potential for capturing carbon inorganically as calcium carbonate. SUCCESS will make recommendations for artificial soil design, plant selection and vegetation management that optimizes ecosystem services in urban landscapes with carbon capture on a lifecycle basis.

The following sections discuss the possible effects the placement of carbon capture plots on transport-based infrastructure may have, as well as the requirements and guidelines for implementation.

\section{SEQUESTRATION OF TRANSPORT-BASED EMISSIONS USING SOILS}

\subsection{Roadside verges and central reserves on highways}

There is potential to utilize roadside verges and central reserve in order to absorb carbon. The total UK carbon footprint in 2015 (provisional) is approx. $523.1 \mathrm{t} \mathrm{CO}_{2} \mathrm{e}$ (5\% lower than 2014) [10]. The UK government has a $\mathrm{CO}_{2}$ reduction target of $80 \%$ by 2050 , based on the 1990 baseline of $771.9 \mathrm{t} \mathrm{CO}_{2} \mathrm{e}$. This translates to a target reduction of around $248.8 \mathrm{t}$. Road transport accounts for $22 \%$ (117 $\left.\mathrm{t} \mathrm{CO}_{2} \mathrm{e}\right)$ of total UK transport emissions and is a major contributor to climate change [11]. In order to estimate the level of emissions offset that the carbon capture product has upon vehicle emissions, projected scenario data from the national transport model, which is designed to forecast long-term trends, is used [12].

Table 1 summarizes the variations between forecast scenarios from the transport model. There are three key uncertainties that were chosen to focus on in the scenarios: (i) propensity for travel (as reflected in trip rates); (ii) the cost of travel and ability to pay for it (as reflected in fuel costs and income growth); and (iii) the extent to which rising incomes lead to higher rates of car ownership and car use [12]. These uncertainties are reflected in the five forecast scenarios. Scenarios 1, 4 and 5 use central, high and low estimates of income and fuel cost, Scenario 2 removes the link between income growth and travel and Scenario 3 explores the impact of alternative assumptions for future trip rates.

Figure 2 illustrates the total greenhouse gas emissions by transport mode on highways (all types of road). The rate of carbon absorption over time is illustrated by the deployment of dolerite quarry fines (basalt material, which is a prime candidate for carbon capture). Based on previously demonstrated carbonation rates, $66 \%$ of the motorway's transport emissions

Table 1: Summary of variations between forecast scenarios.

\begin{tabular}{|l|l|l|l|}
\hline Requirements & Trip rates & Income relationship & Macroeconomic \\
\hline Scenario 1 & Historical average & Positive and declining & Central \\
\hline Scenario 2 & Historical average & Zero & Central \\
\hline Scenario 3 & Extrapolated trend & Positive and declining & Central \\
\hline Scenario 4 & Historical average & Positive and declining & High oil, low GDP \\
\hline Scenario 5 & Historical average & Positive and declining & Low oil, high GDP \\
\hline
\end{tabular}




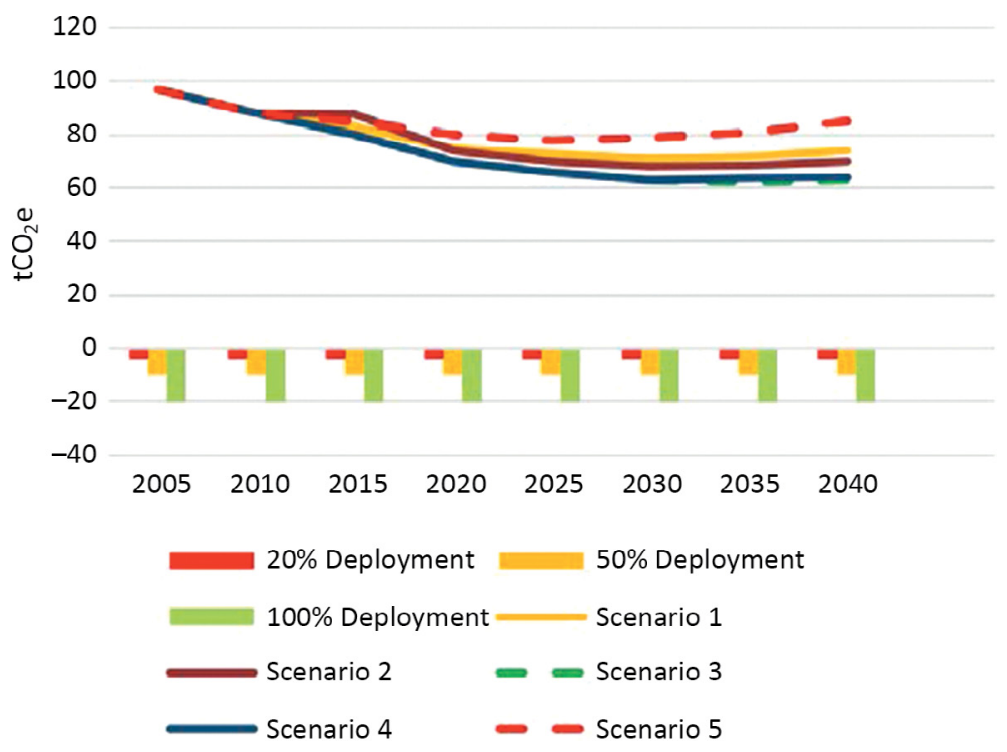

could be offset annually in the UK per annum. This accounts for a $25 \%$ reduction across all highway routes. The EU has agreements with vehicle manufacturers that aim to reduce the average $\mathrm{CO}_{2}$ emissions from new cars. However, these emissions are intensified on the major routes of motorways. The roadside verges on UK's motorways account for over 238,000 ha; if strategically managed to optimize carbon capture through carbonate precipitation alone, hypothetically, this area could remove $2.5 \mathrm{t} \mathrm{CO}_{2}$ per year from the atmosphere, equivalent to $1 \% 2011$ total UK emissions or $2 \%$ of current transport emissions and saving an equivalent of $£ 1.1$ billion in non-traded mitigation values [13]. It is feasible to carry out carbon capture operations on the roadside; although the central reserve also provides land, this may be unfeasible due to the significant level of lane closures required. What is currently unknown is how the carbon capture function will be affected by the proximity of vehicles and the high intensity of $\mathrm{CO}_{2}$ emissions.

\section{IMPLEMENTATION CHALLENGES}

The primary challenges facing implementation are those of logistics and economics. Closing roads, for example, is not an option. Implementation therefore has to be associated with planned projects or when roads are completely closed for improvements, such as widening. In addition, it may be unfeasible to remove roadside land with mature trees of dense grass sward, which would primarily affect economical values; therefore in some cases it may only be possible to build on new roads depending on the density and location of the roadside verges and substrates. Some issues may arise which could interfere with the carbon capture function. Grant et al. [14] highlight the increased levels of $\mathrm{CO}_{2}$ caused by road and vehicle 'runoff' where chemical residues are contaminating the surrounding roadside and wider areas. According to Euripidou and Murray [15] storm water and major flooding can cause road runoff where debris from car exhausts, worn tyres and engine parts, brake linings, paint and rust from vehicles gets passed onto the roadside. Potential contaminants include 


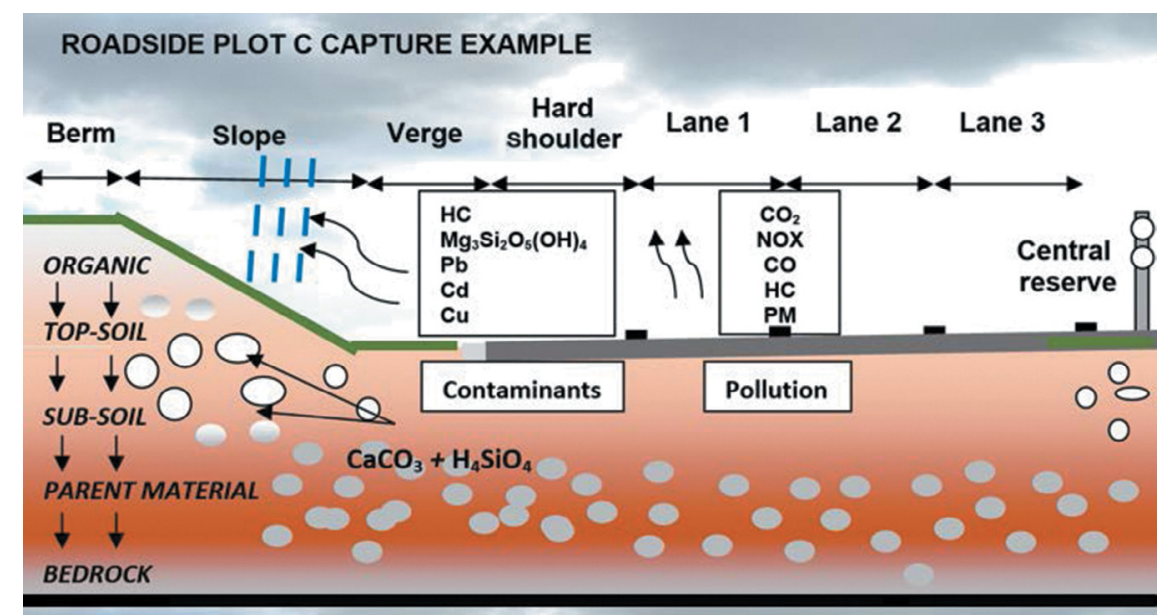

\section{RAILTRACK PLOT C CAPTURE EXAMPLE}

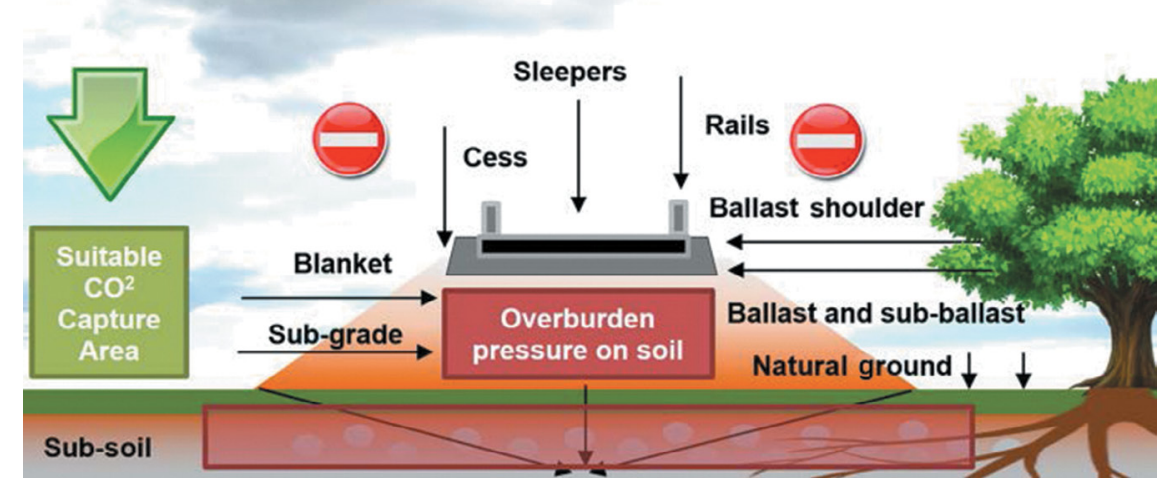

Figure 3: Top: UK Dual 3 Lane motorway environmental effects and proposed carbon capture plots on roadside verges. Bottom: Rail track plot example and carbon capture placement guidance.

hydrocarbons, asbestos, lead, cadmium and copper. Figure 3 (top) illustrates a typical UK Dual Lane highway with a carbon capture function on the roadside verge.

Embankments built as the foundation for railway tracks need to follow special design principles and protocols such as those shown in Fig. 3 (bottom). The embankment's construction protocol largely depends on the type of substrate soil and usually varies in different countries in the world based on the standards they use for the design and construction of the embankments. In principle, embankments must provide sufficient bearing capacity to support overburden pressures [16] caused by the railway track and static and dynamic loads caused by the train running on the track. Accordingly, rail-side carbon capture plots should be built at a safe distance from the embankment of the railway tracks to avoid potential interference with the stability of the embankment and ultimately the railway track. The exact safe distance from the embankment depends on factors such as the type of material used, substrate soil type, size of the railway track and static and dynamic loads caused by the train. 


\section{REQUIREMENTS AND RECOMMENDATIONS FOR SUSTAINABILITY}

\subsection{Life cycle assessment}

Life cycle assessment and material flow analysis play a key role in determining emissions from cradle to grave in the sense that all GHGs are included, converted to the common currency of $\mathrm{CO}_{2}$ global warming potential based on a particular time horizon of 100 years. Life cycle assessment (LCA) was established in the 1990s [17-19]. It is currently being supported by the international ISO standard ISO 14040:2006. It has been subject to criticism by the academic community due to the resource-intensive data collection and computation needed. Subsequent recalibration and harmonization in methodology has led to clearer outcomes. The two approaches that dominate in the literature are 'attributional' and 'consequential' [17, 20, 21]. The former is essentially an estimate valid at the current point in time and calculated based on historical data. The consequential approach considers marginal and major changes to a system, whether this change occurred in the past, present or the future [22-24]. In other words, feedback effects of the world and ecosystem affect the outcomes of the analysis. Kolosz et al. [25] determined that in order to keep embedded $\mathrm{CO}_{2}$ emissions to a minimum the placement of the site with regard to the suppliers should be at its shortest distance (no longer than $200 \mathrm{~km}$ each way); otherwise the duration of the plots to become $\mathrm{CO}_{2}$ negative will increase drastically. The logistical chain should use environmentally friendly vehicles in order to reduce the payback rate of the embedded emissions within the lifecycle.

An additional carbon capture component should be installed in order to provide extra sequestration support in the form of vegetation through careful use of logistics; carbon absorption would take two years to offset embedded emissions (emissions used to in the creation of a product), from the preparation and delivery of the carbon capture material to the selected site. The most appropriate approach for mineral carbonation would be consequential LCA, where the effects of external changes during the analysis timeframe can be understood.

Once the approach is selected there is the option to perform either a simplified (streamlined) or a full LCA. The former can be preferable due to it being affordable and quick to calculate, whilst the latter increases accuracy at the cost of intensive data collection. The streamlined process includes three steps. First, a proper method should be selected to combine adequate accuracy with acceptable cost burden in order to guide decision making. Actually, in the LCA process, besides streamlined LCA, eco-screening and complete LCA are usually considered as well. However, the streamlined one could only provide limited details, with the latter with more detailed information being more expensive. Second, a single measure of stress should be selected. Typical LCA output includes resource consumption, energy consumption, water consumption, emission of $\mathrm{CO}_{2}$, toxic residues and so on. One of these outputs is used as the main factor to measure in streamlined LCA. Energy consumption and $\mathrm{CO}_{2}$ emission are often regarded as 'practical indicators'. Last, stress selected in step 2 is used as a standard to assess the phase of life separately and identify the most damaging phase. For instance, for a family car, energy consumption could be used as the single stress factor to assess each phase of life. The result shows that the most energy-intensive phase for a family car is the usage stage.

Finally, in terms of selecting the lifecycle stages for mineral carbonation, as crushed concrete is a by-product of the demolition process but is in fact considered part of the disposal/ recycling phase of a building, it is not necessary to include these upstream phases due to the material being recycled for another purpose, i.e. the context of use is different. 


\subsection{Material flow analysis}

Material flow analysis (MFA) is an analytical method for quantifying flows and stocks of materials or substances in a well-defined system [26]. MFA is an important tool to assess the physical consequences of human activities and needs in the field of industrial ecology, where it is used on different spatial and temporal scales. Examples are accounting of material flows within certain industries and connected ecosystems, determination of indicators of material use by different societies and development of strategies for improving the material flow systems in the form of material flow management. Material flow analysis can be utilized in order to track the materials that are to be used in the carbon capture sites.

\subsection{Sustainability indexing}

In order to map sustainability, it is important to identify and justify appropriate criteria which would assist in the development of the sustainability framework. Table 2 illustrates

Table 2: Proposed sustainability criteria for transport-based carbon sequestration projects.

\begin{tabular}{|c|c|c|c|}
\hline Requirements & Description & Metric & Potential results/outcomes \\
\hline $\begin{array}{l}\text { Rate and } \\
\text { duration of } \\
\text { absorption }\end{array}$ & $\begin{array}{l}\text { The rate of } \mathrm{C} \\
\text { sequestration }\end{array}$ & $\begin{array}{l}\mathrm{tCO}_{2} / \\
\mathrm{ha} / \mathrm{yr}\end{array}$ & $\begin{array}{l}\text { At the moment it is predicted that } \\
85 \mathrm{t} \mathrm{CO}_{2} / \text { ha/yr can be achieved using } \\
\text { crushed concrete from demolition. }\end{array}$ \\
\hline $\begin{array}{l}\text { Flood } \\
\text { containment }\end{array}$ & $\begin{array}{l}\text { Maintaining the } \\
\text { strict regulations of } \\
\text { the road network } \\
\text { operator's require- } \\
\text { ments of flood } \\
\text { prevention }\end{array}$ & Varies & $\begin{array}{l}\text { Reinforced flood containment operat- } \\
\text { ing within the parameters of the road } \\
\text { network operator. }\end{array}$ \\
\hline Biodiversity & $\begin{array}{l}\text { Species richness } \\
\text { and abundance of } \\
\text { plants and animals }\end{array}$ & Varies & $\begin{array}{l}\text { Vegetation growth is monitored care- } \\
\text { fully by most highway network opera- } \\
\text { tors and must be checked to ensure that } \\
\text { the carbon capture material does not } \\
\text { hinder this. }\end{array}$ \\
\hline $\begin{array}{l}\text { Contaminant } \\
\text { prevention }\end{array}$ & $\begin{array}{l}\text { Preventing con- } \\
\text { taminants from } \\
\text { interfering with } \\
\text { the sequestration } \\
\text { process }\end{array}$ & Varies & $\begin{array}{l}\text { Contaminants should be monitored } \\
\text { regularly to determine the possibility } \\
\text { of interference on the carbon capture } \\
\text { function. }\end{array}$ \\
\hline $\begin{array}{l}\text { Embedded } \\
\text { emissions }\end{array}$ & $\begin{array}{l}\text { The total green- } \\
\text { house gas emis- } \\
\text { sions associated } \\
\text { with implementing } \\
\text { the carbon capture } \\
\text { scheme }\end{array}$ & $\begin{array}{l}\mathrm{tCO}_{2} \mathrm{e} / \\
\mathrm{yr}\end{array}$ & $\begin{array}{l}\text { Greenhouse gas emissions related to the } \\
\text { production and delivery of the carbon } \\
\text { capture material. This determines the } \\
\text { 'carbon debt' and the number of years } \\
\text { that elapse before the project has a net } \\
\text { positive impact. }\end{array}$ \\
\hline $\begin{array}{l}\text { Traded mitiga- } \\
\text { tion costs/sav- } \\
\text { ings }\end{array}$ & The value of $\mathrm{CO}_{2}$ & $£ / t \mathrm{CO}_{2} \mathrm{e}$ & $\begin{array}{l}\text { Using cost benefit analysis the total } \\
\text { monetary savings of carbon sequestra- } \\
\text { tion can be calculated. }\end{array}$ \\
\hline
\end{tabular}


the key parameters that carbon capture soil would need in order to function at its maximum effectiveness.

\subsection{Cost benefit analysis}

Cost benefit analysis (and its discounting method) has a central role in determining the feasibility of current and future road transport projects. Sentance [27] argues that to create and maintain a low carbon policy it is necessary to implement emissions trading and taxation where both mechanisms have individual benefits; however, not all parties may perceive the mechanisms as a positive measure. It is also recommended that they be suited to a particular region or sector; therefore the literature recommends a sectoral approach [28, 29].

\section{CONCLUSIONS}

This article has introduced the multi-functional properties of urban soils, moving beyond sequestration to identify site compatibility issues and steps to be taken in order to achieve harmony and balance within the local ecosystem. Passive soil carbon sequestration has the potential to offset localized transport emissions through the construction of carbon capture urban soil material. The results show that such technology can offset approximately $66 \%$ of highway road user emissions per year. A sustainability framework has been introduced in order to capture the potential characteristics of the performance of the carbon capture function.

\section{ACKNOWLEDGEMENTS}

The authors wish to acknowledge UK funding of the SUCCESS project by the Engineering and Physical Sciences Research Council (EP/K034952/1 and EP/I002154/1).

\section{REFERENCES}

[1] Boot-Handford, M.E., Abanades, J.C., Anthony, E.J., Blunt, M.J., Brandani, S., Mac Dowell, N., Fernandez, J.R., Ferrari, M.-C., Gross, R., Hallett, J.P., Haszeldine, R.S., Heptonstall, P., Lyngfelt, A., Makuch, Z., Mangano, E., Porter, R.T.J., Pourkashanian, M., Rochelle, G.T., Shah, N., Yao, J.G. \& Fennell, P.S., Carbon capture and storage update. Energy \& Environmental Science, 7(1), pp. 130-189, 2014. DOI: 10.1039/ C3EE42350F.

[2] Schmidt, M.W.I., Torn, M.S., Abiven, S., Dittmar, T., Guggenberger, G., Janssens, I.A., Kleber, M., Kogel-Knabner, I., Lehmann, J., Manning, D.A.C., Nannipieri, P., Rasse, D.P., Weiner, S. \& Trumbore, S.E., Persistence of soil organic matter as an ecosystem property. Nature, 478(7367), pp. 49-56, 2011. DOI: 10.1038/nature10386.

[3] Washbourne, C.-L., Lopez-Capel, E., Renforth, P., Ascough, P. \& Manning, D.A.C., Rapid removal of atmospheric $\mathrm{CO} 2$ by urban soils. Environmental Science \& Technology, 2015. DOI: 10.1021/es505476d.

[4] Berner, R.A., Lasaga, A.C. \& Garrels, R.M., The carbonate-silicate geochemical cycle and its effect on atmospheric carbon dioxide over the past 100 million years. American Journal of Science, 283(7), pp. 641-683, 1983. DOI: 10.2475/ajs.283.7.641.

[5] Berner, R.A. \& Lasaga, A.C., Modeling the geochemical carbon cycle. Scientific American, 260, pp. 74-81, 1989. DOI: 10.1038/scientificamerican0389-74.

[6] Nettleton, W.D., Occurrence, characteristics, and genesis of carbonate, gypsum, and silica accumulations in soils. SSSA special publication (USA), 1991. 
[7] Renforth, P. \& Manning, D.A.C., Laboratory carbonation of artificial silicate gels enhanced by citrate: Implications for engineered pedogenic carbonate formation. International Journal of Greenhouse Gas Control, 5(6), pp. 1578-1586, 2011. DOI: 10.1016/j. ijggc.2011.09.001.

[8] Manning, D.A.C., Renforth, P., Lopez-Capel, E., Robertson, S. \& Ghazireh, N., Carbonate precipitation in artificial soils produced from basaltic quarry fines and composts: An opportunity for passive carbon sequestration. International Journal of Greenhouse Gas Control, 17, pp. 309-317, 2013. DOI: 10.1016/j.ijggc.2013.05.012.

[9] Jorat, M.E., Goddard, M.A., Kolosz, B.W., Sohi, S. \& Manning, D.A.C., Sustainable Urban Carbon Capture: Engineering Soils for Climate Change (SUCCESS), in the 16th European Conference on Soil Mechanics and Geotechnical Engineering (XVI ECSMGE 2015). Edinburgh, UK, 2015.

[10] DECC, UK Greenhouse Gas Emissions - 1st Quarter 2015 Provisional Figures, UK Greenhouse Gas Emissions, ed. D.o.E.a.C. Change, Department of Energy and Climate Change: London, UK, 2015.

[11] Highways England, Highways Agency Carbon Routemap: Oppurtunities for a national low carbon transportation, ed. ARUP, 2014.

[12] DfT, Road Traffic Forecasts 2015, ed. DfT, DfT: London, 2015.

[13] DfT, Transport Appraisal Guidance A3 (3.4): Greenhouse Gas Emissions. Department for Transport: London, 2014.

[14] Grant, S., Rekhi, N., Pise, N., Reeves, R., Matsumoto, M., Wistrom, A., Moussa, L., Bay, S. \& Kayhanian, M., A review of the contaminants and toxicity associated with particles in stormwater runoff. Terminology, 2, p. 2, 2003.

[15] Euripidou, E. \& Murray, V., Public health impacts of floods and chemical contamination. Journal of Public Health, 26(4), pp. 376-383, 2004. DOI: 10.1093/pubmed/ fdh 163 .

[16] Montanelli, F. \& Recalcati, P. Geogrid reinforced railways embankments: design concepts and experimental test results. IABSE Symposium Report. International Association for Bridge and Structural Engineering, 2003.

[17] Finnveden, G., Hauschild, M.Z., Ekvall, T., Guinée, J., Heijungs, R., Hellweg, S., Koehler, A., Pennington, D. \& Suh, S., Recent developments in life cycle assessment. Journal of Environmental Management, 91(1), pp. 1-21, 2009. DOI: 10.1016/j.jenvman.2009.06.018.

[18] Guinée, J., Udo de Haes, H. \& Huppes, G., Quantitative life cycle assessment of products:: 1: Goal definition and inventory. Journal of Cleaner Production, 1(1), pp. 3-13, 1993. DOI: 10.1016/0959-6526(93)90027-9.

[19] Guinée, J.B., Heijungs, R., Udo de Haes, H.A. \& Huppes, G., Quantitative life cycle assessment of products: 2. Classification, valuation and improvement analysis. Journal of Cleaner Production, 1(2), pp. 81-91, 1993. DOI: 10.1016/0959-6526(93)90046-E.

[20] Rebitzer, G., Ekvall, T., Frischknecht, R., Hunkeler, D., Norris, G., Rydberg, T., Schmidt, W., Suh, S., Weidema, B. \& Pennington, D., Life cycle assessment: Part 1: Framework, goal and scope definition, inventory analysis, and applications. Environment International, 30(5), pp. 701-720, 2004. DOI: 10.1016/j.envint.2003.11.005.

[21] Mathiesen, B.V., Münster, M. \& Fruergaard, T., Uncertainties related to the identification of the marginal energy technology in consequential life cycle assessments. Journal of Cleaner Production, 17(15), pp. 1331-1338, 2009. DOI: 10.1016/j. jclepro.2009.04.009. 
[22] Sandén, B.A. \& Karlström, M., Positive and negative feedback in consequential lifecycle assessment. Journal of Cleaner Production, 15(15), pp. 1469-1481, 2007. DOI: 10.1016/j.jclepro.2006.03.005.

[23] Brander, M., Tipper, R., Hutchison, C. \& Davis, G., Consequential and attributional approaches to LCA: a guide to policy makers with specific reference to greenhouse gas LCA of biofuels. Technical paper TP-090403-A, Ecometrica Press: London, UK, 2009.

[24] Chen, I.C., Fukushima, Y., Kikuchi, Y. \& Hirao, M., A graphical representation for consequential life cycle assessment of future technologies. Part 1: methodological framework. The International Journal of Life Cycle Assessment, 17(2), pp. 119-125. 2012. DOI: 10.1007/s11367-011-0356-9.

[25] Kolosz, B.W., Goddard, M.A., Jorat, M.E., Sohi, S. \& Manning, D.A.C., Developing lifecycle inventory indices for estimating the carbon sequestration of artificially engineered soils and plants. 5th Asian Conference on Sustainability, Energy, and the Environment. Kobe, Japan, 2015.

[26] Brunner, P.H. \& Rechberger, H., Practical handbook of material flow analysis. The International Journal of Life Cycle Assessment, 9(5), pp. 337-338, 2004. DOI: 10.1007/ BF02979426.

[27] Sentance, A., Developing transport infrastructure for the Low Carbon Society. Oxford Review of Economic Policy, 25(3), pp. 391-410, 2009. DOI: 10.1093/oxrep/grp026.

[28] Millard-Ball, A. Transport in the Global Carbon Market: Baseline Challenges With Sectoral No-Lose Targets, Washington DC, 2010.

[29] Fujiwara, N., The merit of sectoral approaches in transitioning towards a global carbon market. CEPS Special Report, Centre for European Policy Studies, 2010. 